Binghamton University

The Open Repository @ Binghamton (The ORB)

$9-20-2018$

\title{
Capacity, sustainability, and the community benefits of municipal utility ownership in the United States
}

George C. Homsy

Binghamton University--SUNY, ghomsy@binghamton.edu

Follow this and additional works at: https://orb.binghamton.edu/public_admin_fac

Part of the Public Administration Commons

\section{Recommended Citation}

Homsy, George C., "Capacity, sustainability, and the community benefits of municipal utility ownership in the United States" (2018). Public Administration Faculty Scholarship. 48.

https://orb.binghamton.edu/public_admin_fac/48

This Article is brought to you for free and open access by the Public Administration at The Open Repository @ Binghamton (The ORB). It has been accepted for inclusion in Public Administration Faculty Scholarship by an authorized administrator of The Open Repository @ Binghamton (The ORB). For more information, please contact ORB@binghamton.edu. 
Capacity, sustainability, and the community benefits of municipal utility ownership in the United States

George C. Homsy

Department of Public Administration

Sustainable Communities Program

Binghamton University, Binghamton, New York USA

Email:ghomsy@binghamton.edu

Tel: 01-607-777-9184

\section{Declaration of Conflicting Interests}

I have no potential conflicts of interest with respect to the research, authorship, and/or publication of this article.

\section{Funding}

This research was supported in part by a 2014 United States Department of Agriculture, Agriculture and Food Research Initiative, Foundational Agricultural Economics and Rural Development grant (\#2014-68006-21834). 
Capacity, sustainability, and the community benefits of municipal utility ownership in the United States

\begin{abstract}
Most literature on utility sustainability focuses on internal operations; this misses the role that utilities cold play within a community. This study measures the impact of municipal ownership of water and electric utilities on the sustainability policymaking of local governments. I find that municipalities with government-owned water utilities adopt more sustainability measures than those with investor-owned service. Similarly, municipally-owned electric utilities have higher levels of energy sustainability in the community, but not in government operations. The utilities provide fiscal and technical capacity to municipalities. This study brings potential community benefits to the discussion of private investment in public service delivery.
\end{abstract}

Keywords: Local government, sustainability policymaking, municipal utilities, electricity, water

\title{
Policy Highlights:
}

- Municipal ownership of electric and water utilities correlates to increased community water sustainability and community energy sustainability.

- Utilities can provide capacity of local government action on sustainability in the community.

- Interdepartmental coordination also predicts increased sustainability action by a local government.

\section{Introduction}


Water and electric utilities are intimately tied to sustainability through the nature of their services. However, most examinations of the benefits or challenges of such service delivery focus on internal operations. For example, local officials may ask if a water provider delivers a cleaner product at a lower price? Or how quickly electricity is restored after a blackout? External community impacts, such as whether the municipality encourages conservation, are rarely figured into calculations of whether services should be delivered publicly or privately.

At the same time, most local governments in the United States struggle with sustainability (Svara, 2011). Capacity is a key constraint of any action by local governments (Thompson, 1965) with more complex issues, such as sustainability, requiring more capacity (Honadle, 2001). This capacity comes in the form of financial resources or technical expertise. Previous studies have found the lack of capacity to hinder environmental protection policymaking by local governments (Lubell, Feiock, \& Handy, 2009; Sharp, Daley, \& Lynch, 2011). The problem is particularly acute in smaller and rural communities, which do not have the resources or political will to act on many sustainability issues (Carter \& Culp, 2010; Homsy \& Warner, 2015).

Qualitative research in small U.S. cities hints that municipal electric utilities provide an important alternative revenue source in support of sustainability efforts in otherwise poorly resourced communities (Homsy, 2018). Municipally-owned electric utilities allow citizens to be more involved in sustainability discussions, provide local capacity for policymaking, and the technical resources needed for implementation (Feiock, Yi, Matkin, \& Cartes, 2012; Homsy, 2016). Other studies similarly suggest that there are important side benefits to the government delivery of public services and downsides to private provision. For example, using an index of 64 local services, Warner and Hefetz (2002) found that an increase in private delivery correlates 
to decreased levels of civic engagement and increased inequity. Also, in the United Kingdom rates of service delivery by the private sector are negatively associated with social equity (Andrews \& Entwistle, 2010).

In this paper, I follow-up and expand upon these preliminary investigations about the benefits of public ownership of utilities to the greater community using a comprehensive dataset of policymaking by municipalities around the United States. In the next section, I examine the literature around the internal and external benefits of either publicly- or investor-owned utilities. Following the literature review, I present the descriptive results of the national survey and the methodology for modeling the impact of utility ownership on community sustainability from the perspective of the municipality, which is my unit of analysis. My findings indicate that municipal ownership of a water utility positively predicts water sustainability policymaking by that local government. The presence of a municipal electric company correlates to increased policymaking by a city or town in the greater community. But, it does not predict increased energy sustainability policies within local government operations. The study also found cooperation among local government departments to be a strong predictor of sustainability policymaking.

\section{Public versus private utilities}

Since the 1980s, the debate over the privatization of public services has spanned both ideological and practical spectrums (Sclar, 2000). More than 40 percent of public goods are delivered by the private sector (Peters, 2012). Privatization of public services results from general opposition to government involvement in the economic sector, belief in the efficiency of free markets, and as an easy way to raise large sums of money quickly (Patterson, 2013). The World Bank and International Monetary Fund support privatization to raise funds to reduce debt 
and to alleviate the perceived inefficiencies of public operations (Basu \& Miroshnik, 2015). The massive financial investment required in aging water systems drives the calls for privatization in developed countries, especially in response to increased European or US quality standards (Dore, Kushner, \& Zumer, 2004; Lieberherr \& Fuenfschilling, 2016; National Research Council, 2002). Local government leaders in the U.S. make pragmatic decisions around whether or not to outsource service delivery (Kim \& Warner, 2016). The cost-benefit analysis of privatization is situational and based on factors such as community size, structure of local government, market conditions, and scale of services provided (Bel \& Warner, 2015; Pérez-López, Prior, ZafraGómez, \& Plata-Díaz, 2016). In addition to financial considerations, local leaders examine whether or not the public or private provision of services, including power and water utilities, aligns with the public values and institutions (Brown, Potoski, \& Van Slyke, 2006). Public officials have to balance a variety of stakeholder values, which traditionally have included issues of effectiveness, efficiency, equity, accountability, and service quality. Constraining community values are the existing institutions (laws and organizations).

Within the realm of publicly-owned utility companies, governance structure varies. Many operate as city departments (or as sub-units of, for example, a department of public works), which report to elected officials. They can also be independent city agencies, city-owned corporations, utility districts, or regional authorities (Baer, Edelman, Ingram III, \& Mahnovski, 2001). There also exist various forms of privatization that result in different degrees of ownership and risk assumption. For water utilities in the United States, the four most prominent are: the outsourcing of specific support services; contracting operations of publicly-owned facilities; integrating private design, build, and operation of expanded facilities; and the outright sale of facilities to private water companies (National Research Council, 2002). 
Similarly, regulatory schemes for both public and private utilities vary across countries and among states in the United States. Regulation of utilities, since they often involve large investments in fixed assets, must protect consumers, who rely on the safe and consistent delivery of a service, as well as offer investors (or taxpayers in the case of publicly-owned ventures) the assurance that the financial investment will be relatively secure. In the United States, privatelyowned water utilities are regulated for water quality and public health standards by state governments pursuant to the national Safe Drinking Water Act (National Research Council, 2002). Nearly all states also set economic regulations, which control prices and profits of these monopolistic operations. In most states, publicly-owned utilities are not subject to economic regulations (Beecher \& Kalmbach, 2013). Regulation of water service across European nationstates is similarly decentralized and varied with most countries seeking to deal with operations and asset management and pricing (Boscheck, 2013).

In the U.S., investor-owned electric utilities are governed by rules set out by state utility commissions; a few states extend these to publicly-owned utilities. The rules revolve around rates and profit controls. Many states regulate sources of power (portfolio standards) often to encourage renewable power production. About half of state governments also impose energy efficiency standards (Lazar, 2016). Prices vary from state to state within the United States depending upon fuel source, regulation, and other factors. This differs significantly from electricity governance in the European Union where legislation over the years had sought to create an interconnected continent with a convergence of prices and a requirement for the universal provision of service to all households (Erbach, 2016).

\section{U.S. Electricity Provision}


In 2014, the 2,012 electric municipal utilities represented 60.9 percent of all power companies in the United States, but provided electricity to only 14.5 percent of customers (American Public Power Association, 2017). Although some big cities, such as Los Angeles, California, Seattle, Washington, Orlando, Florida, and Austin, Texas have government-owned power companies, the vast majority of the publicly-owned electric companies serve 10,000 customers or fewer. Most of the municipally-owned power companies must purchase power; only 31.9 percent produce any of their own electricity and, of those, nearly three-quarters (72\%) generate five megawatts or less. By contrast, there are 187 invest-owned utilities that provide power to over two-thirds (68.3\%) of customers in the United States.

The prime period of growth for government-owned power companies waned in the early $20^{\text {th }}$ century. Before 1937, the majority of the power in three states and at least 20 percent of electricity in 14 others was generated by municipal utilities (Hausman \& Neufeld, 2011). Private utilities originally focused on large cities, commercial establishments, and the homes of the wealthy. Municipal operations emerged to provide power to rural communities and common people as well as to counter the growing economic and political clout of the investor-owned operations (Rudolph, 2016). Many municipal electric utilities served as money making ventures for cities in order to support other operations (MacKillop, 2005).

The growth of municipal power stopped in the early 1920s and private power companies boomed as utilities and their holding companies became a favorite financial instrument. Leaders among private power companies and equipment makers colluded to prevent government-owned utilities from growing (Granovetter \& McGuire, 1998). Private utilities allowed themselves to be regulated as a monopoly and this blunted public criticism as people and businesses were interested in stable rates and reliable service rather than the battle between public or private 
operations (Rudolph, 2016). Large electric grids with multiple points of generation became technically possible and economically more efficient (Hausman \& Neufeld, 2011). This played to the advantage of investor-owned utilities because most publicly-owned ones were restricted to serving customers within their municipal borders (Rudolph, 2016).

The number of publicly-owned power companies grew again in the middle of the century with the support of Presidents Franklin Roosevelt and Harry Truman. However, the private companies roared back during the administration of President Dwight Eisenhower, who sought to dismantle the federal power projects that favored municipal utilities. In the 1980s, in the U.S. rising rates caused by nuclear plant construction incentivized a small number of local governments to municipalize their power companies (Rudolph \& Ridley, 1986) though the larger result was deregulation in many states. More recently, Boulder, Colorado voted to municipalize their power system in order to forward their goal of becoming a carbon neutral city (Rudolph, 2016). However, from about 1983 to 2013 only 59 government-owned utilities formed (American Public Power Association, 2013).

The impact of power companies within communities is not well studied. Nearly all of the literature focuses on the environmental or social impact of utility operations. A number of the publicly-owned utilities in big cities have established themselves as leaders in renewable energy production, though the broad finding that municipal utilities hold more renewable energy in their portfolios may be due to investments in hydropower (Heiman \& Solomon, 2004). One quantitative analysis found that the presence of a municipal utility reduced the community's likelihood having signed the Mayor's Climate Protection Agreement (Krause, 2011) and another found that municipal utilities drive community-wide energy sustainability efforts (Homsy, 2016). Investments in solar energy by private power companies are negatively correlated to a firm's 
financial performance (Ruggiero \& Lehkonen, 2017). However, even publicly-owned power companies that undertake overseas commercial operations shift away from sustainability values to more profit-driven ones when they leave their home countries (Clifton, Fuentes, \& Warner, 2016).

The most important community benefit discussed in the literature is the potential for economic development based upon lower costs of power from municipal electric utilities. From the beginning, government-provided power has been cheaper than the electricity from private sector operations (Rudolph, 2016). The lower rates are touted as attractive to industries, and municipal utilities were often established to encourage economic development and city expansion (MacKillop, 2005). The American Public Power Association (2017) compiled data showing that in 2014 publicly-owned power companies charged 14 percent less to residential customers than investor-owned utilities. The difference in commercial electricity rates is narrower: 11.1 cents per kilowatt-hour for customers investor-owned utilities versus 10.7 cents for government-owned companies. In a handful states, such as Alaska, California, Connecticut, Maryland, and Nevada, public power prices are much lower than those of investor-owned utilities. In 12 states, the average publicly-owned rate was slightly above that of investor-owned utilities.

Another advantage noted in the literature is that government-ownership can give citizens control over the kinds of power generated. For example, citizen pressure forced municipal utilities in Seattle, Washington and Austin, Texas to not participate or to sell off investments in nuclear projects (Rudolph, 2016). As a result, these utilities developed aggressive communitywide conservation programs. Burlington, Vermont's publicly-owned utility became a leader in energy efficiency only after an outcry by citizens. At the same time municipally-owned power 
companies have better relationships with their customers, which facilitates the increased marketing of energy conservation programs (Wilson, Plummer, Fischlein, \& Smith, 2008).

Literature on social sustainability and utilities is thin and usually describes the challenges of reaching low income households with energy efficiency. For example, Bird and Hernández (2012) find that the split incentive problem, in which renters pay utility bills while landlords must bear the costs of energy efficiency improvements, is the main reason that weatherization programs have had very low penetration among low income households. In addition, low income households have been underserved by utility conservation programs because residents lack the money to make initial improvements (Evens, 2015). Over time, the poorer energy customers will be bear the burden of increased solar installations, which drive up the fixed costs of power production that utilities will pass on to customers (Oppenheim, 2016).

\section{U.S. Drinking Water Provision}

The ownership profile of water utilities is the opposite that of electric companies in the United States. While neoliberal reforms have allowed privatization in much of the power, transportation, and telecommunications markets, the water sector remains largely a governmentowned operation due to its nature as an essential public good with expensive infrastructure requirements and sensitivity to environmental threats (Lieberherr \& Fuenfschilling, 2016). Although the private provision of water has grown since the beginning of the $21^{\text {st }}$ century (Varghese, 2007), by 2014, for-profit companies operated only 46 percent of U.S. water systems and served only 12 percent of customers (Food and Water Watch, 2016). Governments owned 51 percent of the systems while providing drinking water to 87 percent of the U.S. population.

(These numbers exclude individual systems, usually wells.) From 2007 to 2014 the portion of the 
population served by municipal utilities rose about three percent.

Privatization of the aging water systems across developed countries seeks to bring new, non-governmental investment in desperately needed infrastructure improvements (Lieberherr \& Fuenfschilling, 2016). The nature of water makes it a challenging good for privatization as it remains inexpensive to customers compared to its value for life and its cost of transportation (Solomon, 2011). In places, fiscal constraints and the devolution of financial responsibilities exacerbated the capacity limits facing local governments seeking to upgrade water systems - and pushed the hunt for alternatives (Furlong, 2016).

In the United States, water systems most likely to privatize were in municipalities with middle income residents, which may indicate that private suppliers seek communities who can afford rate increases, but without significant political influence (Greiner, 2016). In the United Kingdom, privatization set off a wave of re-regulation as a backlash to the private operation's environmental and social impacts, such as water service disconnections, cherry-picking of the most lucrative areas to provide service, and the increased risks to public health (Lieberherr \& Fuenfschilling, 2016). However, even public utilities face justice issues, such as in Detroit where thousands of low-income families had their water shut off or Chicago where water rates rose 45 percent over three years (Vanderwarker, 2012). Case studies of utilities in Zurich, Berlin, and Leeds indicate a potential tradeoff among the three sustainability dimensions: privately owned operations tend to be more economically efficient at the expense of the environment and social justice while publicly-owned water utilities sacrifice economic efficiency in favor of the other two values (Lieberherr \& Truffer, 2015).

As with electric utilities, the examination of benefits associated with public or private ownership of water companies focuses on the operations themselves. Investor-owned water 
utilities in Europe tend to be more innovative than their public counterparts, but do less in terms of sustainability (Lieberherr \& Truffer, 2015). Smaller utilities struggle with broad sustainability goals due to technical and fiscal limitations as well as lacking access to industry-wide standards in areas outside of public health (Haider, Sadiq, \& Tesfamariam, 2016). Landis (2015) surveyed 125 water utilities across North America and, without reporting on differences by ownership, found that only 18 percent had a sustainability policy or vision statement and only four percent had a sustainability coordinator. Nearly half (46\%) employed no internal sustainability metrics. Despite the energy intensive nature of most water utility operations, only 30 percent have undertaken energy audits or energy conservation strategies. A multi-state study of utilities ( $n=80)$ in the Midwest, again without differentiating by ownership, found that the vast majority did not have rate structures conducive to conservation; 60 percent charged customers lower rates with higher water usage and another 31 percent held the rates constant regardless of amount of water used with a few more private utilities having such conservation discouraging policies. Just over two-thirds of the utilities (71\%) provided conservation information to customers. The study also found that 11 percent of utilities have discounts for low-income customers; 10 percent have senior discounts; and 26 percent offer some kind of payment assistance program (Beecher \& Kalmbach, 2013).

\section{Measuring municipal utilities and the local sustainability landscape}

The unit of analysis in this study is the local or county government. My measures of the community benefits are three additive indices of local government sustainability policies drawn from the 2015 Local Government Sustainability Practices Survey conducted with the International City/County Management Association. The survey frame consisted of all counties, 
all municipalities and townships over 25,000 in population and a one in 2.5 sample of municipalities and townships with between 2,500 and 24,999 people. The survey was mailed to the chief administrative officer of all 8,562 local governments in this universe and had a response rate of 22.2 percent with 1,899 counties and municipalities responding. After cleaning returns and matching them with U.S. Census data, I ended up with 1,839 observations in the sample.

\section{Dependent variables}

Tables one through three show descriptive statistics for the components of each of the dependent variables used in this study. The three dependent variables are additive indices of policies adopted by local governments in three areas: water sustainability, energy sustainability in local government operations, and energy sustainability in the community.

[Insert Tables 1, $2 \& 3$ about here.]

\section{Independent variables}

The main independent variable of interest is the presence of a municipal utility, based on survey questions asking whether or not the respondent's community owned their own electricity or water utility. In model one, which examines the predictors of water sustainability, the presence of a publicly-owned water utility is used. In the other two models, I use the presence of a publicly-owned electric company. Only 10.3 percent of respondents owned their power company while 55.9 percent of water utilities did. I expect that the presence of a municipal water 
utility or a municipal electric utility will be positively correlated to increased rates of sustainability policies adopted by the local government.

The second independent variable measures state influence. In the United States, the policy options of local governments are limited by the rules of their particular state. Also, many states govern the actions of utilities operating within their borders. This variable is an additive index of state-level conservation policies and regulations. The state influence score for the water model is derived from The Water Efficiency and Conservation State Scorecard (Christiansen et al., 2012). The state influence score for electricity policy is a count of climate mitigation and energy conservation policies compiled by the Center for Climate and Energy Solutions (2011). I expect that state influence scores will be positively correlated to sustainability outcomes.

The third variable is an indication of whether or not departments within the local government cooperate on water or energy sustainability. Sustainability requires collaboration across administrative units. The data come from two questions on the 2015 sustainability survey. For electricity, the survey asks whether there is cooperation on energy planning. For water, the question was about collaboration on stormwater management. I expect that collaboration across department silos will increase the sustainability of particular places.

The fourth group of variables deals with capacity. The property tax dependence variable is calculated from 2012 U.S. Census of Government data (property tax revenue / total revenue). The council manager variable comes from ICMA records supplemented with additional research to fill in missing places. The percent with a bachelor's degree comes from the 2015 U.S. American Community Survey Five-Year Estimates. The percent of communities reporting staff dedicated to sustainability comes from the sustainability survey. I expect that all of these variables will be positively correlated to sustainability as demonstrated in previous studies. 
The fifth variable category is metropolitan status. Previous studies have found that urban areas will be more likely to have more sustainability policies than suburban and rural areas. Finally, I use as control variables population size, population density, and percent of the population that identifies as white; all of these come the 2010 U.S. Census. The descriptive statistics for these variables are found in Table 4.

[Insert Table 4 about here]

\section{Estimation Procedure}

I ran three separate models, one for each dependent variable, to examine the role of the presence of a municipal utility and other predictors on local government sustainability policymaking. I used the same sample of 1,839 local and county governments for each model. The dependent variables are comprised of count data that have an over-dispersed Poisson distribution. Therefore, I employed a negative binomial regression model. The likelihood ratio test that alpha equals zero is significant confirming that the negative binomial model is a more appropriate fit than a Poisson one. Since state governments are the main regulators of utilities in the United States, I also controlled for states in order to account for various political environments and regulatory effects that would not show up in the state influence score independent variable. The results are presented in Table 5 as incident rate ratios, which, in this case, means the change in predicted count of policies when the particular independent variable increases by one unit.

[Insert Table 5 about here.] 


\section{Limitations}

The study has important limitations. First, as previously described, both publicly- and privately-owned utilities come in various governance and corporate forms. Testing the impact of these structures on financial and sustainability outcomes is beyond the scope of the current study and a topic of future research. Second, despite the sample size, a Chi-Square Goodness of Fit test indicates that the largest municipalities in the sample (100,000 or more) and the smallest (under 25,000) are slightly overrepresented while the communities between 25,000 and 99,999 are underrepresented. In the sample, 15 percent of communities were principal cities or counties, 54 percent suburbs, and 30 percent rural communities. Urban and suburban jurisdictions are somewhat overrepresented and rural underrepresented. Finally, there is likely a self-selection bias towards places that undertake sustainability actions, though this limitation may also strengthen the final result as I am testing whether local governments with municipal utilities adopt more sustainability policies. The bias towards more sustainable communities may make a positive finding more robust.

\section{Drivers of municipal sustainability}

The main independent variable of interest is whether or not the local government owns the water or energy utility. In two of the three models the presence of the municipal utility is significant, and it is a strong and positive predictor of increased numbers of municipal policies with regards to water sustainability actions and community-wide sustainability actions. It is not significant with regards to energy sustainability policies undertaken by the local government, such as installing solar panels on government buildings or conducting energy audits of government facilities and operations. (See Table 2 for the full list.) The findings confirm the 
differing role of municipal utilities with regards to municipal electric utilities using a different dataset (Homsy, 2016).

Why might municipal utilities predict increased community-wide policies, but not sustainability policies within government operations? First, making government energy operations more efficient has a direct impact on the bottom line of any municipality. Although some places may have a hard time making initial investments in energy upgrades, the payoff for is easy for local leaders to recognize and to tout - with or without a municipal utility driving the change. Second, it is relatively easier for government to change its own operations than to work on changes in the private sector, where returns from initial public investments may not be quickly realized by the local government. Community values around renewable energy and conservation can vary dramatically and local leaders must walk a fine line when spending municipal funds to support community resident or business sector efforts.

A third factor might be the need for greater capacity to handle the more complex challenge of community-wide energy sustainability. In the second model, which examines government energy sustainability, municipal utilities do not play a role, but other capacity variables do. Both property tax dependence and the presence of a city manager, two standard capacity variables, are only significant in this second model and not the others. This juxtaposition between the presence of a municipal electric utility and two standard capacity variables provides support for the notion that municipal utilities provide important technical and fiscal capacity to carry out a variety of sustainability actions - without a publicly-owned utility local governments that do adopt energy sustainability policies in the community rely on other avenues of capacity for implementation. The presence of sustainability staff is significant in all models, which is consistent with previous research about the importance of this technical and 
administrative capacity. The percent of the population with a college degree is also significant in all of the models, which is common among studies using this as a proxy for citizen capacity.

Interdepartmental cooperation is significant in the three models. Policy integration across administrative silos is theoretically important to sustainability action (Feiock, Krause, \& Hawkins, 2017). The current effort is the one of the first studies to empirically examine the impact of interdepartmental collaboration on sustainability. Perhaps communities more inclined to promote sustainability policy also tend to be more collaborative. Also, with their cash flow and expertise, municipal utilities may be attractive collaborators around sustainability issues in city government. This administrative aspect of sustainability requires more empirical investigation.

The role of the state is not significant in any of the models. This runs counter to previous findings (Homsy \& Warner, 2015), which indicate that sustainability often requires the state to create a political environment conducive to action as well as supply funding and expertise. With regards to energy and water utilities, state rules often govern internal operations, for example, a minimum amount of renewable power or investment in water conservation measures. The narrowness of the dependent variables might explain this deviation from past studies, which look at a broader set of sustainability policies. Also, the dataset may be biased towards places that act on sustainability, especially on this limited set of policies, and this may cover up any role that the state may have in pushing a green agenda.

The size of a municipality is significant and positive in all three models. Density is significant in the energy sustainability in government operations model though the coefficient indicates that the size of the relationship is small. The percentage of the population that is white 
is insignificant in all three models. In the government operations model, suburban and rural communities adopt fewer sustainability policies.

\section{The Role for Municipal Utilities}

This study confirms the important role that municipal utilities - both water and energy can have as actors within a community around the issue of sustainability. Local governments, after the Great Recession, must find alternative ways to fund the kinds of public services they provide (Kim \& Warner, 2016). The low rate of sustainability policy adoption (Svara, 2011) indicates that local leaders have trouble prioritizing these sustainability values over more immediate and traditional quality of life concerns. The challenge is particularly acute in smaller communities, which the research shows have harder times adopting sustainability policies and the results here indicate may be struggling with both the fiscal and technical capacity.

Local values may be driving re-municipalization of utilities in Europe. Since the turn of the $21^{\text {st }}$ century, water delivery in France and electricity delivery in Germany have increasingly been provided by local governments (Hall, Lobina, \& Terhorst, 2013). In 2000, 80 percent of Germany's electricity and 75 percent of France's water was delivered by private companies. Since then, five major French water providers, covering about five million people, have been taken over by the public with no providers moving to the private sector. In Germany there have been 162 re-municipalizations of power companies and none in the opposite direction. In both nations, three reasons drove the changes: the expiration of existing private contracts, customer mistrust over prices and performance, and the rise of green politicians and sustainability values among the populace. 
Such a radical change is not expected in the United States. One of the most prominent remunicipalizations in recent years was in Boulder, Colorado as the citizens grew frustrated with their investor-owned utility's unwillingness to align practices with rising sustainability values. The debate on whether to take over the electric company was contentious (Driskell, 2012) and the transition has been anything but smooth. With costs of municipalization mounting, Boulder put the takeover on the ballot again in 2017 - for the third time in seven years. Once again voters supported the re-municipalization effort (Burness, 2017). Boulder's experience demonstrates the potential for a community to promote its environmental values with a locally owned utility (Crandall, Bailey, Gichon, \& Koehn, 2014), although the struggles and costs incurred by one of the most progressive cities in the United States does not bode well for other re-municipalization efforts.

Instead, the case for municipal utilities may lie in the unrealized potential of these organizations in smaller, under-resourced communities. The Poisson distribution of the dependent variables (the counts of sustainability actions) indicates that most of the values are low. For the 1,027 places in the sample with a publicly-owned water utility, the median number of water sustainability policies is 1 and the mean is 1.4 , out of a range of 0 to 6 . Similarly, the 190 communities with a municipal electric company average only 1.6 community-wide energy policies with a median of three; and this is out of a possible 17 policies. Despite the results that show the importance of publicly-owned utilities as a driver, there are obviously many places where the utility is not pushing for sustainability. In these places, the revenues may either go to keeping electricity or water costs down (which is a potentially anti-conservation approach) or into the general budget to offset other costs of running a government. Local leaders may not 
recognize the sustainability asset they have, may not care to pursue such an agenda, or have such a fragmented governance environment that money and talent cannot be easily repurposed.

Another possible reason for the lack of action in communities with municipal utilities is that promoting sustainability can work against their immediate financial self-interest. Water and energy conservation is counter-intuitive when your business is to sell these as products (Homsy, 2016). The return on investments, for example, in renewable power or grey water re-use systems may take too long to be realized. In many places, the balance of values shifts to economic efficiency over sustainability, especially with cash-strapped local governments tapping into the utility revenue stream for more traditional community needs.

The previous point indicates a number of important areas of future research. In places with publicly-owned water and public utilities, what drives people to act? Do local leaders or citizens push sustainability and see municipal utilities as a vehicle for implementation? Or can municipal utilities initiate sustainability actions on their own? What role does the local nature of the utility play versus the public ownership? For example, could a local privately-owned utility have the same impact? Would a public-private partnership allow community values around issues of sustainability to be merged with the efficiencies and capital investment potential of the private sector? At the same time, there are a variety of ownership structures of municipal utilities. How different might the sustainability actions of those that are municipal departments be from those that are standalone authorities or those that have more corporatized operations? Another important area of future research is the effectiveness of consumer collective purchasing organizations, known as community energy projects, in which the members seek to influence environmental and social policies of providers. These have the potential to be broad social movements rather than just local efforts (Becker, Kunze, \& Vancea, 2017). An evaluation of 
rural electrical and other cooperatives as representative of community sustainability values (or not) is also warranted.

Such ongoing research is crucial as two major developments are pending. First, in the electricity sector, new renewable technologies as well as smart grids or distributed systems means that practitioners and scholars will have to soon rethink the operations of utilities and their role in communities. With these changes, existing and current industrial operators will jockey for power and market position (Hess, 2013). Much of the discussion will likely focus on the tension between utilities values and the sustainability values of certain communities. Second, and similarly, massive infrastructure investments will be needed to maintain the drinking water system in the United States and in other developed countries around the world. There is likely to be a push to fund those improvements through private sector operations including public-private partnerships, which can be structured numerous ways and which may provide public service operations with the investment and technical expertise for needed infrastructure transitions (Delmon, 2017). As governments weigh whether or not to bring the private sector deeper into utility operations, the calculation must be more than financial. In this paper I have shown that important community benefits of municipal ownership can be seen and need to be part of the public versus private service delivery discussion. 


\section{References}

American Public Power Association. (2017). The 2016-2017 Annual Directory \& Statistical Report. Washington, DC: American Public Power Association. Retrieved from http://www.publicpower.org/Programs/Landing.cfm?ItemNumber=38710\&navItemNum ber $=37577$

Andrews, R., \& Entwistle, T. (2010). Does Cross-Sectoral Partnership Deliver? An Empirical Exploration of Public Service Effectiveness, Efficiency, and Equity. Journal of Public Administration Research and Theory, 20(3), 679-701. https://doi.org/10.1093/jopart/mup045

Baer, W., Edelman, E. D., Ingram III, J., \& Mahnovski, S. (2001). Governance in a Changing Market: The Los Angeles Department of Water and Power. Santa Monica, CA: RAND. Retrieved from https://www.rand.org/pubs/monograph_reports/MR1189.html

Basu, D., \& Miroshnik, V. (2015). Privatization of Electricity. In International Business and Political Economy (pp. 165-173). Palgrave Macmillan, London. https://doi.org/10.1057/9781137474865_17

Becker, S., Kunze, C., \& Vancea, M. (2017). Community energy and social entrepreneurship: Addressing purpose, organisation and embeddedness of renewable energy projects. Journal of Cleaner Production, 147, 25-36. https://doi.org/10.1016/j.jclepro.2017.01.048

Beecher, J. A., \& Kalmbach, J. A. (2013). Structure, regulation, and pricing of water in the United States: A study of the Great Lakes region. Utilities Policy, 24, 32-47. https://doi.org/10.1016/j.jup.2012.08.002 
Bel, G., \& Warner, M. E. (2015). Inter-Municipal Cooperation and Costs: Expectations and Evidence. Public Administration, 93(1), 52-67. https://doi.org/10.1111/padm.12104

Bird, S., \& Hernández, D. (2012). Policy options for the split incentive: Increasing energy efficiency for low-income renters. Energy Policy, 48(Supplement C), 506-514. https://doi.org/10.1016/j.enpol.2012.05.053

Boscheck, R. (2013). Procurement, Privatisation, Principles and Presumptions The EU's Proposed Concessions Directive and the Governance of Water Supply. Intereconomics, 48(3), 136-139. https://doi.org/10.1007/s10272-013-0456-9

Brown, T. L., Potoski, M., \& Van Slyke, D. M. (2006). Managing Public Service Contracts: Aligning Values, Institutions and Markets. Public Administration Review, 66(3), 323331.

Burness, A. (2017, November 8). Boulder's muni lives as voters reaffirm support for local electric utility. Daily Camera. Retrieved from http://www.dailycamera.com/boulderelection-news/ci_31437049/boulder-municipalization-tax

Carter, R., \& Culp, S. (2010). Planning for Climate Change in the West (Policy Focus Report No. Code PF024). Cambridge, MA: Lincoln Institute of Land Policy.

Center for Climate and Energy Solutions. (2011). U.S. Cities and States. Retrieved May 25, 2012, from https://www.c2es.org/us-states-regions

Christiansen, W., Dickinson, M. A., Schempp, A., Herzog, M., Mirvis, K., \& Loftus, A. (2012). The Water Efficiency and Conservation State Scorecard: An Assessment of Laws and Policies. Chicago \& Washington, DC: Alliance for Water Efficiency \& Environmental Law Institute. Retrieved from http://www.allianceforwaterefficiency.org/finalscorecard.aspx 
Clifton, J., Fuentes, D. D., \& Warner, M. (2016). The loss of public values when public shareholders go abroad. Utilities Policy, 40, 134-143. https://doi.org/10.1016/j.jup.2015.11.003

Crandall, K., Bailey, H., Gichon, Y., \& Koehn, J. (2014). Turning a Vision to Reality: Boulder's Utility of the Future. In F. P. Sioshansi (Ed.), Distributed Generation and its Implications for the Utility Industry (pp. 435-452). Boston: Academic Press. https://doi.org/10.1016/B978-0-12-800240-7.00022-9

Delmon, J. (2017). Public-Private Partnership Projects in Infrastructure: An Essential Guide for Policy Makers. Cambridge University Press.

Dore, M. H. ., Kushner, J., \& Zumer, K. (2004). Privatization of water in the UK and FranceWhat can we learn? Utilities Policy, 12(1), 41-50. https://doi.org/10.1016/j.jup.2003.11.002

Driskell, D. (2012, August). The Power to Decide: Boulder's Energy Future. Presented at the City and Regional Planning Colloquium Series, Cornell University, Ithaca NY.

Erbach, G. (2016). Understanding electricity markets in the EU (p. 10). European Union: European Parliamentary Research Service. Retrieved from http://www.europarl.europa.eu/RegData/etudes/BRIE/2016/593519/EPRS_BRI(2016)59 3519_EN.pdf

Evens, A. (2015). The Utility of the Future and Low-Income Households. The Electricity Journal, 28(10), 43-52. https://doi.org/10.1016/j.tej.2015.11.008

Feiock, R. C., Krause, R. M., \& Hawkins, C. V. (2017). The Impact of Administrative Structure on the Ability of City Governments to Overcome Functional Collective Action 
Dilemmas: A Climate and Energy Perspective. Journal of Public Administration Research and Theory. https://doi.org/10.1093/jopart/mux021

Feiock, R. C., Yi, H., Matkin, D. S. T., \& Cartes, D. (2012). Municipal-owned utilities and demand side management. In 2012 IEEE Power and Energy Society General Meeting (pp. 1-9). https://doi.org/10.1109/PESGM.2012.6345376

Food and Water Watch. (2016). The State of Public Water in the United States. Washington, DC: Food and Water Watch. Retrieved from https://www.foodandwaterwatch.org/sites/default/files/report_state_of_public_water.pdf

Furlong, K. (2016). Leaky Governance: Alternative Service Delivery and the Myth of Water Utility Independence. UBC Press.

Granovetter, M., \& McGuire, P. (1998). The making of an industry: electricity in the United States. Sociological Review, 46, 147-173. https://doi.org/10.1111/j.1467954X.1998.tb03473.x

Greiner, P. T. (2016). Social Drivers of Water Utility Privatization in the United States: An Examination of the Presence of Variegated Neoliberal Strategies in the Water Utility Sector. Rural Sociology, 81(3), 387-406. https://doi.org/10.1111/ruso.12099

Haider, H., Sadiq, R., \& Tesfamariam, S. (2016). Intra-utility performance management model (In-UPM) for the sustainability of small to medium sized water utilities: Conceptualization to development. Journal of Cleaner Production, 133, 777-794. https://doi.org/10.1016/j.jclepro.2016.06.003

Hall, D., Lobina, E., \& Terhorst, P. (2013). Re-municipalisation in the early twenty-first century: water in France and energy in Germany. International Review of Applied Economics, 27(2), 193-214. https://doi.org/10.1080/02692171.2012.754844 
Hausman, W. J., \& Neufeld, J. L. (2011). How politics, economics, and institutions shaped electric utility regulation in the United States: 1879-2009. Business History, 53(5), 723746. https://doi.org/10.1080/00076791.2011.599589

Heiman, M. K., \& Solomon, B. D. (2004). Power to the People: Electric Utility Restructuring and the Commitment to Renewable Energy. Annals of the Association of American Geographers, 94(1), 94-116. https://doi.org/10.1111/j.1467-8306.2004.09401006.x

Hess, D. J. (2013). Industrial fields and countervailing power: The transformation of distributed solar energy in the United States. Global Environmental Change, 23(5), 847-855. https://doi.org/10.1016/j.gloenvcha.2013.01.002

Homsy, G. C. (2016). Powering sustainability: Municipal utilities and local government policymaking. Environment and Planning C: Government and Policy, 34(6), 1076-1094. https://doi.org/10.1177/0263774X15596530

Homsy, G. C. (2018). Unlikely pioneers: creative climate change policymaking in smaller U.S. cities. Journal of Environmental Studies and Sciences, Online First, 1-11. https://doi.org/10.1007/s13412-018-0483-8

Homsy, G. C., \& Warner, M. E. (2015). Cities and Sustainability: Polycentric Action and Multilevel Governance. Urban Affairs Review, 51(1), 46-73. https://doi.org/10.1177/1078087414530545

Honadle, B. W. (2001). Theoretical and practical issues of local government capacity in an era of devolution. Journal of Regional Analysis and Policy, 31(1), 77-90.

Kim, Y., \& Warner, M. E. (2016). Pragmatic Municipalism: Local Government Service Delivery After the Great Recession. Public Administration, 94(3), 789-805. https://doi.org/10.1111/padm.12267 
Krause, R. M. (2011). Policy innovation, intergovernmental relations, and the adoption of climate protection initiatives by U.S. cities. Journal of Urban Affairs, 33(1), 45-60. https://doi.org/10.1111/j.1467-9906.2010.00510.x

Landis, A. E. (2015). The State of Water/Wastewater Utility Sustainability: A North American Survey. Journal - American Water Works Association, 107(9), 91. https://doi.org/10.5942/jawwa.2015.107.0125

Lazar, J. (2016). Electricity Regulation In the US: A Guide. Second Edition (p. 228). Montpelier, VT: The Regulatory Assistance Project. Retrieved from http://www.raponline.org/knowledge-center/electricity- regulation-in-the-us-a-guide-2

Lieberherr, E., \& Fuenfschilling, L. (2016). Neoliberalism and sustainable urban water sectors: A critical reflection of sector characteristics and empirical evidence. Environment and Planning C: Government and Policy, 34(8), 1540-1555.

https://doi.org/10.1177/0263774X15625994

Lieberherr, E., \& Truffer, B. (2015). The impact of privatization on sustainability transitions: A comparative analysis of dynamic capabilities in three water utilities. Environmental Innovation and Societal Transitions, 15, 101-122. https://doi.org/10.1016/j.eist.2013.12.002

Lubell, M., Feiock, R. C., \& Handy, S. (2009). City Adoption of Environmentally Sustainable Policies in California's Central Valley. Journal of the American Planning Association, 75(3), 293-308. https://doi.org/10.1080/01944360902952295

MacKillop, F. (2005). The Los Angeles “Oligarchy” and the Governance of Water and Power Networks. Flux, 60(2), 23-34. 
National Research Council. (2002). Privatization of water services in the United States: an assessment of issues and experience (pp. 40-2905-40-2905). Washington, DC: National Academies Press. Retrieved from https://www.nap.edu/catalog/10135/privatization-ofwater-services-in-the-united-states-an-assessment

Oppenheim, J. (2016). The United States regulatory compact and energy poverty. Energy Research \& Social Science, 18(Supplement C), 96-108. https://doi.org/10.1016/j.erss.2016.04.022

Patterson, W. (2013). Transforming Electricity: The Coming Generation of Change. Routledge. Pérez-López, G., Prior, D., Zafra-Gómez, J. L., \& Plata-Díaz, A. M. (2016). Cost efficiency in municipal solid waste service delivery. Alternative management forms in relation to local population size. European Journal of Operational Research, 255(2), 583-592. https://doi.org/10.1016/j.ejor.2016.05.034

Peters, J. (2012). Neoliberal convergence in North America and Western Europe: Fiscal austerity, privatization, and public sector reform. Review of International Political Economy, 19(2), 208-235. https://doi.org/10.1080/09692290.2011.552783

Rudolph, R. (2016). The Struggle for Public Power in the United States. In N. Pun, B. H. Ku, H. Yan, \& A. Koo (Eds.), Social Economy in China and the World (pp. 115-134). Abingdon, Oxon ; New York, NY: Routledge.

Rudolph, R., \& Ridley, S. (1986). Power Struggle: The Hundred Year War Over Electricity. New York: Harper \& Row Publishers.

Ruggiero, S., \& Lehkonen, H. (2017). Renewable energy growth and the financial performance of electric utilities: A panel data study. Journal of Cleaner Production, 142, 3676-3688. https://doi.org/10.1016/j.jclepro.2016.10.100 
Sclar, E. (2000). You Don't Always Get What You Pay For: The Economics of Privatization. Ithaca, NY: Cornell University Press.

Sharp, E. B., Daley, D. M., \& Lynch, M. S. (2011). Understanding Local Adoption and Implementation of Climate Change Mitigation Policy. Urban Affairs Review, 47(3), 433457. https://doi.org/10.1177/1078087410392348

Solomon, L. D. (2011). America's water and wastewater crisis: the role of private enterprise. New Brunswick, N.J: Transaction Publishers.

Svara, J. H. (2011). The Early Stage of Local Government Action to Promote Sustainability. In The Municipal Year Book 2011 (pp. 43-60). Washington, DC: ICMA Press.

Thompson, V. A. (1965). Bureaucracy and Innovation. Administrative Science Quarterly, 10(1), $1-20$.

Vanderwarker, A. (2012). Water and Environmental Justice. In J. Christian-Smith \& P. H. Gleick (Eds.), A Twenty-First Century U.S. Water Policy (pp. 52-89). Oxford: Oxford University Press.

Varghese, S. (2007). Privatizing US Water. Minneapolis, MN: Institute for Agriculture and Trade Policy. Retrieved from https://www.ircwash.org/sites/default/files/Varghese-2007Privatizing.pdf

Warner, M., \& Hefetz, A. (2002). Applying Market Solutions to Public Services An Assessment of Efficiency, Equity, and Voice. Urban Affairs Review, 38(1), 70-89. https://doi.org/10.1177/107808702401097808

Wilson, E. J., Plummer, J., Fischlein, M., \& Smith, T. M. (2008). Implementing energy efficiency: Challenges and opportunities for rural electric co-operatives and small 
municipal utilities. Energy Policy, 36(9), 3383-3397.

https://doi.org/10.1016/j.enpol.2008.05.007 